HITLER AT HOME 
This page intentionally left blank 


\section{HITLER AT HOME}

\section{DESPINA STRATIGAKOS}

Yale University Press New Haven and London 
Published with assistance from the Graham Foundation for Advanced Studies in the Fine Arts.

Copyright (C) 2015 by Despina Stratigakos. All rights reserved. This book may not be reproduced, in whole or in part, including illustrations, in any form (beyond that copying permitted by Sections 107 and 108 of the U.S. Copyright Law and except by reviewers for the public press), without written permission from the publishers.

yalebooks.com/art

Designed and set in Adobe Garamond type by Lindsey Voskowsky.

Printed in the United States of America by Thomson-Shore, Inc., Dexter, Michigan.

Library of Congress Control Number: 2014953548

ISBN 978-0-300-I838I-8

A catalogue record for this book is available from the British Library.

This paper meets the requirements of ANSI/NISO Z 39.48-I992 (Permanence of Paper).

IO $98765432 \mathrm{I}$

Jacket illustrations: (front) Eva Braun's room in the Berghof with framed Hitler portrait (detail of fig. 3I); (back) detail from cover of Heinrich Hoffmann, Hitler Away from It All (Hitler abseits vom Alltag) (fig. 42). 
To my mother, who lived it 
This page intentionally left blank 